\title{
Fuel consumption efficiency regarding the road quality in the coal mine: a case study
}

\section{Laura Puspita Sari*}

Department of Mining Engineering, Institut Teknologi Nasional Yogyakarta, JL. Babarsari, Caturtunggal, Sleman, Yogyakarta, 55281, Indonesia

\begin{tabular}{l} 
ARTICLE INFORMATION \\
\hline Article history: \\
Received: January 31, 2021 \\
Revised: June 22, 2021 \\
Accepted: June 28, 2021 \\
\hline
\end{tabular}

Keywords:

AFCA

Fuel ratio

Grade

Road maintenance

Cost-benefit

\section{A B S T R A C T}

Fuel requirements have a direct impact on mining activities. The operator's habits influence the amount of fuel used in operating the equipment, the mine road's slope, and the distance predetermined in the mine design planning. Adjustment Fuel Consumption Actual (AFCA) is the fuel cost, which is influenced by the fuel price, distance, and condition of the mining road billed for overburden and coal mining activities carried out by the contractor. The research methodology uses off-site and on-site analysis. Off-site analysis can be carried out the highest 'Fuel Ratio' owned by the machine based on its specifications and operational activities to find out how much fuel consumption is needed to produce the amount of production per hour (liters/bcm). Meanwhile, it needs to be correlated with the mine road's condition, including the slope of the mine road (grade). This study aims to determine the relationship between road grade and fuel consumption by comparing road grade improvement efforts with cost-benefit analysis.

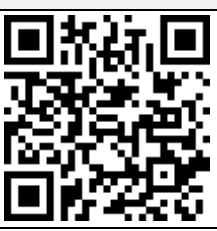

This is an open-access article under the CC-BY-NC-SA license.

*Corresponding Author

Laura Puspita Sari

E-mail: laura@itny.ac.id

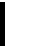

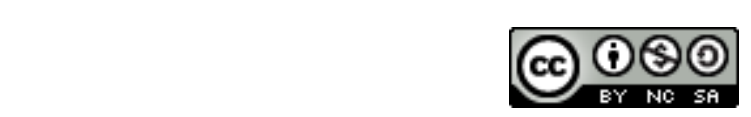

() 2021 Some rights reserved

\section{INTRODUCTION}

The increasing need for tools follows the increasing need for coal production as a means of transportation to assist production activities at the mine, but they also produce some environmental impacts throughout its life cycle due to the high consumption of energy and natural resources [1]. With this condition, fuel needs automatically become the main thing to drive the units that will work in the field. In addition, the use of fuel impacts mining costs, so some companies have to evaluate the use of fuel in each working unit to reduce production costs.

The ratio of dump truck fuel consumption that has been set based on the company's standard parameters is smaller than the actual ratio of fuel consumption in the field. The grade that is often encountered in the field is a grade that exceeds the safety standard, namely grade $<8 \%$. Grade $8 \%$ means that every $100 \mathrm{~m}$, the length of the mine road has a height difference of $8 \mathrm{~m}$. Apart from road slope and mileage factors, the ageing unit condition causes fuel consumption to increase. The unit to be studied in this study is the Caterpillar HD785-7 type unit. The fuel consumption is the largest during the January - March period to move overburdened material to the Disposal area. One way to reduce fuel consumption is to study the 
factors that affect mechanical devices' productivity and fuel consumption. Haul road design for an open pit can significantly influence the associated costs. Designing haul roads for open-pit mines can support efficient truck hauling operations; Besides, the time it takes for the truck movement along the road can be estimated. Therefore, it can help improve the function of road design [2]. So it changes to distance and depth task of material movement will provide accuracy indicator of a vehicle and operator performance [3].

Several studies have previously studied the factors that affect fuel consumption, such as testing fuel consumption through linear regression to identify actual fuel consumption to be used as a recommendation to reduce fuel consumption in mining operational units [4]. Then another factor is the distance segmentation, vertical alignment, and the slope of the road. Based on related research, it explains that by using GPS assistance to find the route in a segment, it is known that if the segment length is too long, then the actual variation within the class is smoothed out incorrectly. Furthermore, the determination of the slope of a road greatly influences the use of fuel emissions [5], [6]. Finally, driving behavior also significantly affects fuel consumption, divided into three main types: defensive, standard, and aggressive [7], [8].

\section{RESEARCH METHODS}

This research was conducted based on secondary data from the SAP "Fuel Consumption" (T-code: ZMC3029R). Secondary data that will be analyzed is field data that has been uploaded in SAP and then analyzed the cost-benefit of AFCA billing against the grade of all mining roads that the operational unit passes. This research method (Fig. 1) includes:

a) Collecting data consisting of details of overburden and coal operational units operating within the timeframe of the research activities, AFCA costs incurred due to mining operations, fuel consumption needs, grade data of all mining roads traversed by operational units, and specifications of the mining operational unit used.

b) Classify the equipment specifications with the largest amount of fuel consumption based on the work area (overburden or coal area)

c) Evaluate the number of units operating through the mine road grade that exceeds the $8 \%$ (standard) stated on the mine map.

d) Calculating the distance of the mine road travelled by the mining operational unit by considering the internal and external factors of the mine by comparing the fairness specifications of the fuel consumption-based

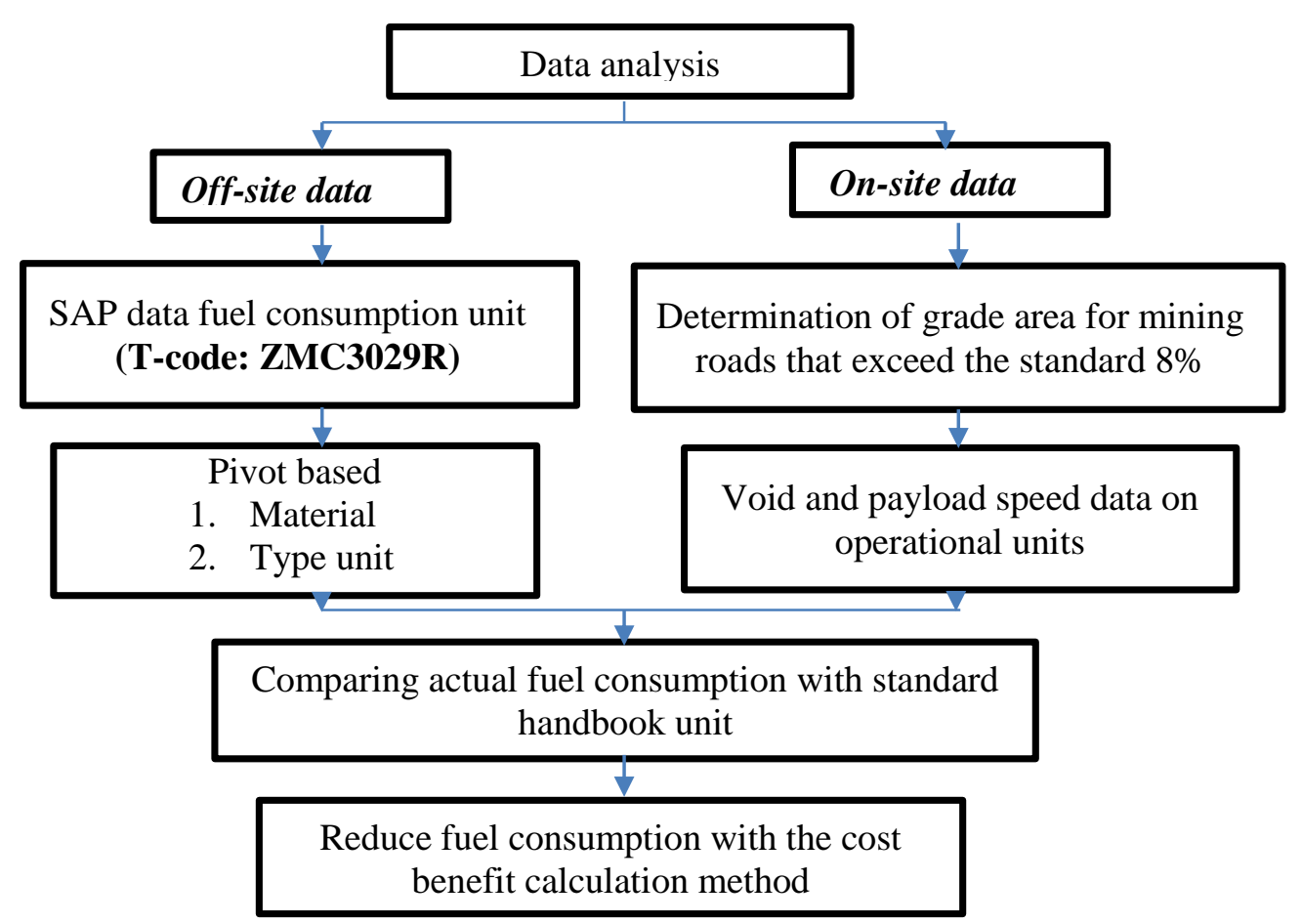

Fig 1. Flowchart of research methods 


\subsection{Adjustment Fuel Consumption Actual (AFCA)}

In calculating the AFCA, the required variable factors are overburden production, average distance, fuel consumption, and fuel price. Here are the steps to calculate AFCA with various factors that affect:

1. Benchmark Fuel Ratio Overburden (BFRO) is the ratio between the amount of fuel consumption to be used with the amount of overburden planned to be unloaded and transported to the disposal area.

$$
B F R O=\frac{\text { fuel consumption }(\text { liters })}{\text { overburden production }(\text { bcm })}
$$

2. Distance Benchmark Overburden (DBO) is when the operational mining equipment must travel from the demolition area to the disposal area. If what is looking for is the average actual distance overburden, then the total distance travelled by the transportation equipment needs to be averaged to get the actual distance.

$$
D B O=\frac{\text { Total Distance }(\mathrm{km})}{\text { amount of data distance }}
$$

3. Variation of Fuel Ratio Actual Overburden (VFRAO) is the ratio between the amount of fuel consumption to be used with the amount of overburden planned to be unloaded and transported until the disposal area is multiplied by the distance of the conveyance that has been previously planned.

$$
V F R A O=B F R O \times D B O
$$

4. Actual Fuel Price (AFP) is the fuel price in the current period, and if there is a change, the actual fuel price can be found by calculating the average price for each current period.

$$
A F P=\frac{\text { Total current period fuel prices }}{\text { Number of periods }}
$$

5. Fuel Ratio Overburden (FRO) is the ratio between the amount of fuel consumption to be used with the amount of overburden planned to be unloaded and transported to the disposal area, which is influenced by the haul distance factor.

6. Fuel Ratio Allowance (FRA) is the ratio between the amount of product produced per period with the total fuel consumption.

$$
F R A=F R O x \text { Total Overburden }
$$

Their productivity is greatly dependent on the haul road condition. Poorly maintained roads or roads surfaced by weak materials are characterized by increased rolling resistance, poor trafficability, and lower productivity [9]. The existing mine haul road maintenance of management strategy is often inappropriate and unresponsive to rapidly changing road conditions. Resulting in less than the optimal implementation of road maintenance strategy by increasing officers in total road users fees and service reductions [10]. Whether the way to reduce costs is effective is by converting the grade reduction into its commercial value, which can be seen from the AFCA value.

\subsection{Mining Road Components}

In the analysis, the determination of fuel demand is strongly influenced by the total resistance generated based on the specifications of the production unit used. And to find out the total resistance required, a special component is needed that must be included as a supporting variable for the calculation, namely 'Grade Resistance' and 'Rolling Resistance'. The reduction of rolling resistance is essential for roads [11]. If under dry sand conditions, rolling resistance increases with speed until the tire begins to "flat ", where it flattens or decreases, modified by the load [12]. The rolling coefficient is the variable needed to calculate the rolling resistance obtained based on the

\begin{tabular}{|c|c|c|}
\hline Category & Conditions & Total resistance \\
\hline Low & $\begin{array}{l}\text { High ratio of loading time to cycle time, good haul conditions } \\
\text { low truck job efficiency. }\end{array}$ & - \\
\hline Medium & $\begin{array}{l}\text { The medium ratio of travelling time to cycle time, a medium loa } \\
\text { factor of a truck, and medium-haul road conditions and grade }\end{array}$ & $\begin{array}{l}\text { Over } 2 \% \text { through } \\
10 \%\end{array}$ \\
\hline High & $\begin{array}{l}\text { High ratio of travelling time to cycle time, a tough load factor } \\
\text { of a truck, several haul road conditions, and grade. }\end{array}$ & $10 \%$ and above \\
\hline
\end{tabular}
road conditions. It is included in the rolling resistance $(\mathrm{Cr})$ category of running car tires, which is 0.0035 .

Table 1. The ratio of fuel consumption criteria to total resistance [13] 
Table 2. Components that are affected during transport by load and empty

\begin{tabular}{|c|c|c|c|c|c|c|c|c|c|c|}
\hline \multicolumn{2}{|c|}{ Activity } & Distance & $* G R$ & $* R R$ & $* T R$ & $\begin{array}{l}\text { Speed } \\
\text { range }\end{array}$ & $\begin{array}{l}\text { Max. } \\
\text { speed }\end{array}$ & $\begin{array}{l}\text { Speed } \\
\text { factor }\end{array}$ & Ave. speed & Time \\
\hline \multirow{3}{*}{$\begin{array}{l}\text { Hauling } \\
\text { (Loaded) }\end{array}$} & Flat & 330 & 0 & $5 \%$ & $5 \%$ & F5 & $36 \mathrm{~km} / \mathrm{h}$ & 0.5 & $300 \mathrm{~m} / \mathrm{min}$ & $1.10 \mathrm{~min}$ \\
\hline & Uphill & 50 & $10 \%$ & $5 \%$ & $15 \%$ & $\mathrm{~F} 2$ & $11 \mathrm{~km} / \mathrm{h}$ & 0.6 & $109.8 \mathrm{~m} / \mathrm{min}$ & $0.46 \mathrm{~min}$ \\
\hline & Flat & 120 & 0 & $5 \%$ & $5 \%$ & F5 & $36 \mathrm{~km} / \mathrm{h}$ & 0.6 & $300 \mathrm{~m} / \mathrm{min}$ & $0.40 \mathrm{~min}$ \\
\hline \multirow{3}{*}{$\begin{array}{l}\text { Returning } \\
\text { (Unloaded) }\end{array}$} & Flat & 120 & 0 & $5 \%$ & $5 \%$ & F6 & $53 \mathrm{~km} / \mathrm{h}$ & 0.35 & $309.1 \mathrm{~m} / \mathrm{min}$ & $0.39 \mathrm{~min}$ \\
\hline & $\begin{array}{c}\text { Down- } \\
\text { Hill }\end{array}$ & 50 & $-10 \%$ & $5 \%$ & $-5 \%$ & F6 & $40 \mathrm{~km} / \mathrm{h}$ & 0.7 & $466 \mathrm{~m} / \mathrm{min}$ & $0.11 \mathrm{~min}$ \\
\hline & Flat & 330 & 0 & $5 \%$ & $5 \%$ & F6 & $53 \mathrm{~km} / \mathrm{h}$ & 0.7 & $618.1 \mathrm{~m} / \mathrm{min}$ & \\
\hline
\end{tabular}

Information : *GR is Grade Resistance; *RR is Rolling Resistance; *TR is Total Resistance

Then from the total resistance can be seen whether the fuel consumption ratio is in the high, medium, or low category (Table 1). This category is based on the total resistance results [13]. The effect of grade on the unit speed is when loaded and empty based on the unit specifications in the Caterpillar handbook (Table 2). The type of road material affects the speed of the vehicles that are active on it [14].

Total resistance is usually called the effective grade, which is the actual ability of a vehicle when climbing a hill. The amount of total resistance is strongly influenced by the amount of grade resistance and rolling resistance, where grade resistance is resistance that arises and must be overcome by the force of the machine. When the unit goes up or moves up, the grade resistance value is positive, whereas if the unit moves down, the grade resistance is worth negative. At the same time, the definition of rolling resistance is the resistance of a wheel based on road conditions [15].

$$
T R=G R+R R
$$

\subsection{Analysis of Cost Opportunity and Cost- Benefit}

This research requires a technical analysis that can be converted commercially to make comparisons in decision-making, so there needs to be a cost opportunity analysis. A cost-benefit study to support the implementation of corrective actions will be taken to decrease the fuel ratio. It has an impact on the AFCA value. So it is necessary to analyze the mining road which results from grade conditions.

\section{RESULTS AND DISCUSSION}

From the results of research conducted both off-site and on-site, the following conditions were obtained.

\subsection{Off-site Analysis}

The off-site analysis is an analysis carried out by comparing the actual data on fuel usage for the three months running (January, February, March) with the fuel consumption budget that has been calculated in the planning through SAP data (System Application Procedure). Data relating to unit activities and operational activities based on the unloaded material can be uploaded easily in the SAP data. After uploading the data, the data can be processed according to research needs. For example, the following is the comparison data between the amount of fuel used for three months with data that has been previously planned or known as budget data (Table 3).

From the comparison between budget fuel and actual, it is found that for three consecutive periods, there has been an increase in the amount of fuel used from the previous plan. Therefore, after finding out that there is a condition of over fuel usage, a classification is made based on the type and total fuel consumption in that period (Table 4).

Table 3. Conditions for excess fuel use with planning data

\begin{tabular}{|c|c|c|c|c|c|}
\hline No & Month & Fuel usage (a) & In budget & Low budget & Over fuel \\
\hline 1 & January & $9,190,584.00$ & $6,777,213.78$ & $1,274,494.00$ & $1,138,876.22$ \\
\hline 2 & February & $7,329,943.00$ & $5,315,100.80$ & $1,197,800.00$ & $817,042.20$ \\
\hline 3 & March & $9,757,518.00$ & $3,337,992.81$ & $5,478,772.00$ & $940,753.19$ \\
\hline & $\begin{array}{l}\text { Total } \\
\text { Percen }\end{array}$ & $\begin{array}{l}26,278,045.00 \\
e(\%)\end{array}$ & $\begin{array}{c}15,430,307.39 \\
58.72 \%\end{array}$ & $\begin{array}{c}7,951,066.00 \\
30.26 \%\end{array}$ & $\begin{array}{c}2,896,671.61 \\
11.02 \%\end{array}$ \\
\hline
\end{tabular}


Table 4. Comparison of the amount of fuel consumption for each type of unit

\begin{tabular}{cccc}
\hline Type unit & January & $\begin{array}{c}\text { Fuel consumption } \\
\text { February }\end{array}$ & March \\
\hline HD785-7 & $3,590,170.00$ & $2,709,177.00$ & $3,765,741.00$ \\
785C & $443,138.00$ & - & - \\
ACTROS4054 & $277,183.00$ & $175,752.00$ & $190,324.00$ \\
D155A-6 & $183,001.00$ & $172,571.00$ & $204,871.00$ \\
GD825A-2 & $138,593.00$ & $126,752.00$ & $150,408.00$ \\
HD465-7 & $137,927.00$ & $100,502.00$ & $151,775.00$ \\
D10R & $64,127.00$ & $44,472.00$ & $48,102.00$ \\
24M & $48,321.00$ & $41,994.00$ & - \\
FM440 FT & $12,120.00$ & - & - \\
D85ESS-2 & $3,553.00$ & - & - \\
FM440 & - & $243,322.00$ & $305,550.00$ \\
D375A-5 & - & $105,591.00$ & $130,971.00$ \\
HD465-7 WT & - & $40,385.00$ & $53,929.00$ \\
773E & - & - & $77,475.00$ \\
\hline
\end{tabular}

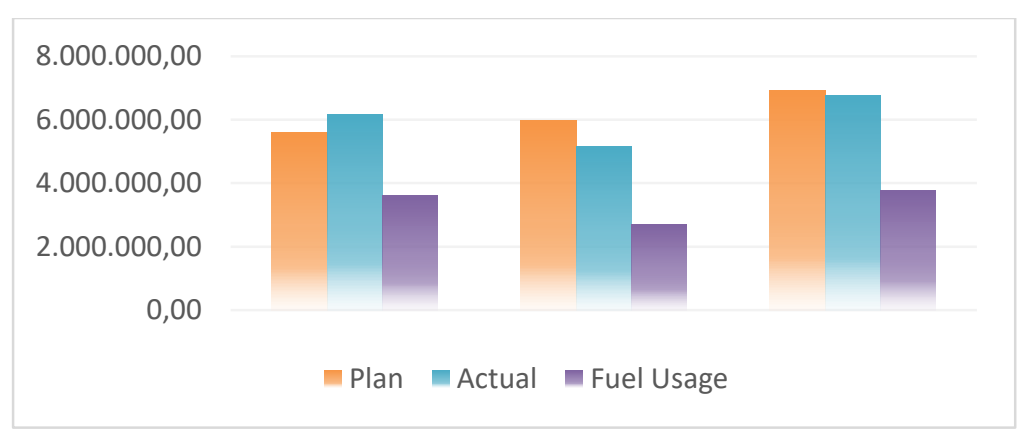

Fig. 2. Comparison of total fuel consumption with production achievement against overburden targets

Table 4 shows that the type of $\mathrm{OB}$ (overburden) material production unit HD785-7 consumes the most fuel. It is because the Overburden production target has increased, but in fact, the off-site analysis that has been examined shows that there is a large consumption of fuel followed by a decrease in the amount of production in the February and March periods (Fig. 2). The impropriety of fuel use with the target amount of overburden production can be seen from the decrease in overburden production, which should be proportional to the amount of fuel consumption.

The data above shows the fuel ratio results, which can be calculated by comparing the fuel usage with the actual amount of overburden production produced. It can also be seen that there is still excessive use of fuel from the total activities of units operating in the field by $11.02 \%$. It is evidenced by the use of excess fuel in 3 consecutive periods for overburden activity.

\subsection{On-site Analysis}

Observations were made in areas where the grade exceeds the standard because this is one of the causes of excess fuel consumption [16]. Observation and data collection was carried out using a speedometer to determine the speed of the production unit operating on the road with grade criteria> $8 \%$ to obtain the time and distance travelled by the production unit in the road area [17]. The mine road design affects the pit limit conditions, so the grade determines the pit depth [18]. There is a relationship between the grade slope and the fuel consumption based on the number of 30 sample units operating in the area where the road slope exceeds the standard (Table $5)$.

It is necessary to do a simple regression test to determine the relationship between the independent variable (fuel consumption) and the dependent variable (grade). From the simple regression test, the equation of the relationship 
between grade and fuel consumption is obtained;

$$
\mathrm{Y}=0.314 \mathrm{X}-15.805
$$

Table 5. Fuel consumption and grade data

\begin{tabular}{ccc}
\hline Sample Fuel consumption (Ltr/hr) & Grade (\%) \\
\hline 01 & 74.67 & 7.35 \\
02 & 74.89 & 7.40 \\
03 & 75.37 & 7.45 \\
04 & 75.37 & 7.55 \\
05 & 75.75 & 7.60 \\
06 & 75.83 & 7.70 \\
07 & 75.87 & 7.90 \\
08 & 75.91 & 8.00 \\
09 & 76.04 & 8.30 \\
10 & 77.06 & 8.50 \\
11 & 77.65 & 8.55 \\
12 & 76.40 & 8.60 \\
13 & 78.50 & 8.80 \\
14 & 78.52 & 8.80 \\
15 & 78.55 & 8.90 \\
16 & 79.22 & 9.20 \\
17 & 79.28 & 9.30 \\
18 & 79.35 & 9.40 \\
19 & 79.40 & 9.70 \\
20 & 79.58 & 9.80 \\
21 & 80.05 & 9.80 \\
22 & 82.60 & 10.0 \\
23 & 84.22 & 10.6 \\
24 & 84.75 & 10.6 \\
25 & 84.38 & 10.6 \\
26 & 84.24 & 10.8 \\
27 & 85.20 & 10.8 \\
28 & 86.50 & 11.2 \\
29 & 86.45 & 11.2 \\
30 & 88.80 & 11.8 \\
\hline
\end{tabular}

The stages to perform a simple regression test are the normality test, heteroscedasticity test, and autocorrelation test with Durbin-Watson. In this study, tests or analyzes carried out in the study used SPSS (Statistical Program for Social Science) v.26 software for windows. From the normality test results, the P-P Plot graph equation regarding the relationship between fuel consumption and grade (Fig. 3).

After obtaining the data, it is necessary to test the normality so that the relationship between the slope of the road and the amount of fuel consumption can be analyzed. From the normality test results, it was found that the Std Deviation value was 0.983 with a total of 30 data. Visually, the variability can be seen from the narrow normality curve (Fig. 4).

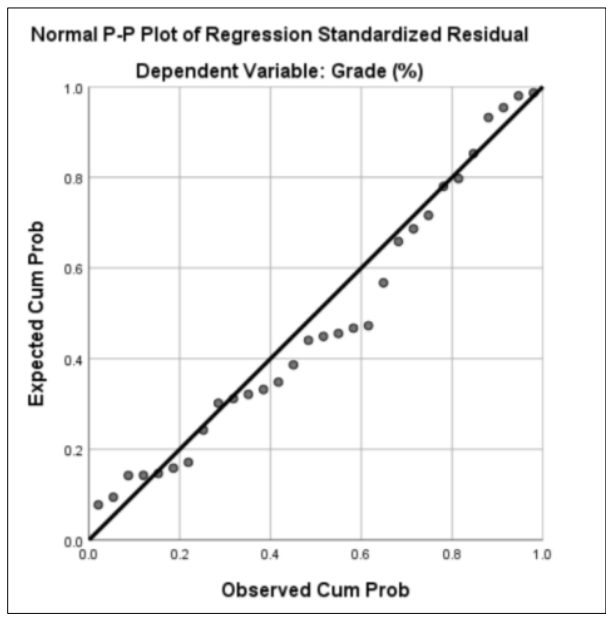

Fig 3. P-P plot

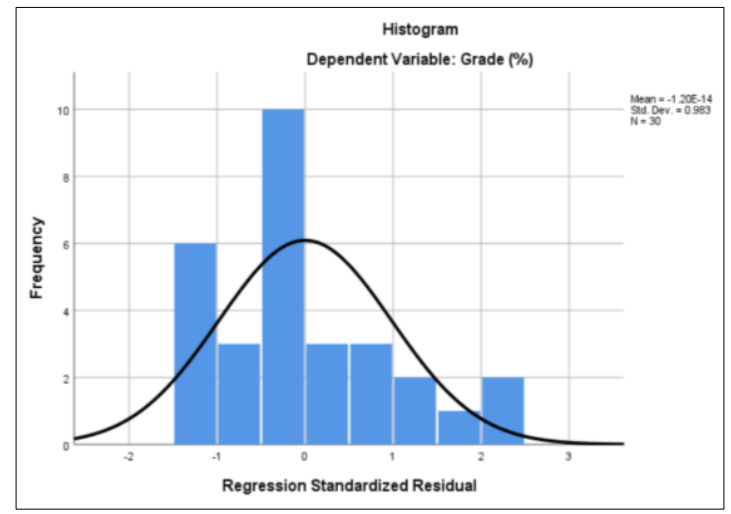

Fig 4. Normality test

Heteroscedasticity indicates the spread of the independent variables. The random distribution shows a good regression model; in other words, there is no heteroscedasticity. Heteroscedasticity can be done by observing a scatterplot graph with a dotted pattern that spreads above and below the Y-axis To test for (Fig. 5).

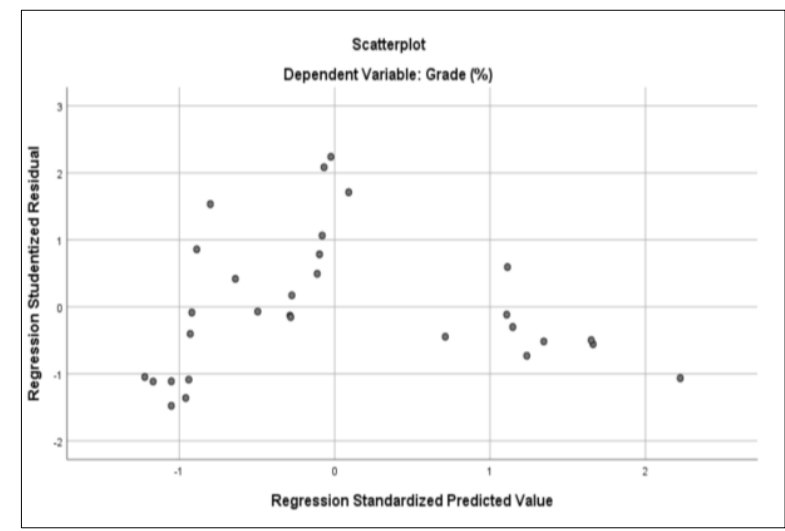

Fig 5. Scatterplot 
The scatterplot graph shows the points spread randomly and are spread above and below the zero on the Y-axis. So it is concluded that there is no Heteroscedasticity in this regression model. Apart from observing the scatterplot graph, the heteroscedasticity test can also be done by using the Glejser Test. Glejser Test is a test by regressing the absolute value of the residuals on the independent variable. The results of the SPSS output display clearly show that all independent variables have a sig value $>0.05$. So there is no independent variable that statistically significant affects the dependent variable abs res. So it can be concluded that the regression model does not occur heteroscedasticity.

Table 6. Result SPSS Durbin-Watson

\begin{tabular}{cccccc}
\hline Model & R & $\begin{array}{c}\text { R } \\
\text { Square }\end{array}$ & $\begin{array}{c}\text { Adjusted } \\
\text { R Square }\end{array}$ & $\begin{array}{c}\text { Std. } \\
\text { Error }\end{array}$ & $\begin{array}{c}\text { Durbin- } \\
\text { Watson }\end{array}$ \\
\hline 1 & 0.977 & 0.955 & 0.954 & 0.28365 & 0.574 \\
\hline
\end{tabular}

Table 6 explained R Square value of 0.954 , which means that between grades affects fuel consumption of $95.4 \%$, and the rest is influenced by other variables not included in this study. The way to detect the presence or absence of autocorrelation in this study is to calculate the DurbinWatson statistical value. For example, table 6 shows the value of Durbin-Watson 0.574 so that the value of $\mathrm{du}$ is 1.459 and $\mathrm{dl}$ is 1.352 . After getting the du and dl values, look for (4-du) and (4-dl). From the results of the autocorrelation test, the value of $\mathrm{d}<\mathrm{dl}$ is obtained, so it can be concluded that there is autocorrelation.

From the field, three unit samples were taken to perform calculation analysis, namely the HDCT78465, HDCT78318, and HDCT78360 units. The sample unit traverses of the mine road condition have a grade of $9.5 \%$. With the unit condition with a maximum load of 166 tons and the effect of gravity, the resistance grade is $15.45 \%$ with a rolling resistance of $0.57 \%$, so that the total resistance is $16.02 \%$. In the Caterpillar Edition 46 Handbook, the total unit resistance specification of 16.02 is included in the high category [18].

Using a speedometer, we can obtain observational data in the form of time and speed; then, from these data, it can be found that the distance travelled by the dump truck unit on a road grade exceeds $8 \%$. The trick with shooting the speedometer at the dump truck five until six times while passing non-standard grades until the dump truck passes the standard road grade to get a correlation between road grade and fuel consumption per hour (Table 7).

After we get the time and distance data from the observation results, then it compiled using the jigsaw unit data, which contains the cycle time of the dump truck and the total rotation in one hour to get the dump truck time passing the nonstandard grade of the total rotation and the time data from the observations. The standard caterpillar handbook with the high (108.2 liters/hr.), medium (77.3 liters/hr.) and low fuel consumption categories (57.7 liters/hr.).

Table 7. Dump truck speed observation data

\begin{tabular}{|c|c|c|c|c|c|c|c|c|c|}
\hline \multirow{2}{*}{ Unit } & \multirow{2}{*}{ Location } & \multirow{2}{*}{$\begin{array}{c}\text { Observation } \\
\text { time }\end{array}$} & \multicolumn{2}{|c|}{ Time Duration } & \multirow{2}{*}{$\begin{array}{l}\text { Total } \\
\text { time } \\
\text { (Hour) }\end{array}$} & \multirow{2}{*}{$\begin{array}{c}\text { Speed } \\
(\mathbf{k m} / \mathbf{h r})\end{array}$} & \multicolumn{2}{|c|}{ Distance } & \multirow{2}{*}{$\begin{array}{c}\text { Total } \\
\text { distance } \\
(\mathbf{m})\end{array}$} \\
\hline & & & Second & Hour & & & km & $\mathbf{m}$ & \\
\hline HDCT & Eco & 4:32:48 PM & & & 0.0125 & & & & 143.06 \\
\hline \multirow[t]{4}{*}{78465} & & 4:32:58 PM & 10 & 0.0028 & & 11 & 0.03 & 30.56 & \\
\hline & & 4:33:08 PM & 10 & 0.0028 & & 8 & 0.02 & 22.22 & \\
\hline & & 4:33:18 PM & 10 & 0.0028 & & 10 & 0.03 & 27.78 & \\
\hline & & 4:33:33 PM & 15 & 0.0042 & & 15 & 0.06 & 62.50 & \\
\hline \multirow{4}{*}{$\begin{array}{l}\text { HDCT } \\
78318\end{array}$} & Eco & 4:40:39 AM & & & 0.0097 & & & & 108 \\
\hline & & 4:40:49 PM & 10.00 & 0.0028 & & 17 & 0.047 & 47.22 & \\
\hline & & 4:40:59 PM & 10.00 & 0.0028 & & 10 & 0.028 & 27.78 & \\
\hline & & 4:41:14 PM & 15.00 & 0.0042 & & 8 & 0.033 & 33.33 & \\
\hline HDCT & Eco & 4:26:58 PM & & & 0.0153 & & & & 165.28 \\
\hline \multirow[t]{5}{*}{78360} & & 4:27:08 PM & 10.00 & 0.0028 & & 8 & 0.022 & 22.22 & \\
\hline & & 4:27:18 PM & 10.00 & 0.0028 & & 15 & 0.042 & 41.67 & \\
\hline & & 4:27:28 PM & 10.00 & 0.0028 & & 13 & 0.036 & 36.11 & \\
\hline & & 4:27:38 PM & 10.00 & 0.0028 & & 10 & 0.028 & 27.78 & \\
\hline & & 4:27:53 PM & 15.00 & 0.0042 & & 9 & 0.038 & 37.50 & \\
\hline
\end{tabular}


From the standard criteria for using fuel by type unit, the actual fuel usage can be calculated based on the handbook, namely by multiplying the observation time recorded in one rotation per hour (Table 8). Factors of speed, distance and time also affect the number of rites. In addition, the slope of the road traversed by each dump truck following the intended disposal area also affects the use of fuel.

Table 8. Jigsaw data

\begin{tabular}{ccccc}
\hline Unit & $\begin{array}{c}\text { Ritation } \\
\text { per shift }\end{array}$ & $\begin{array}{c}\text { Cycle } \\
\text { time }\end{array}$ & $\begin{array}{c}\text { Ritation } \\
\text { per hours }\end{array}$ & $\begin{array}{c}\text { Total } \\
\text { ritation }\end{array}$ \\
\hline HDCT78465 & 22 & 23.68 & 2.53 & 0.03 \\
HDCT78318 & 22 & 23.59 & 2.54 & 0.02 \\
HDCT78360 & 21 & 24.26 & 2.47 & 0.04 \\
\hline
\end{tabular}

Total rotation is obtained from the total rotation per hour multiplied by the total time observed using a speedometer. Then the total rotation is multiplied by the standard handbook Fuel consumption type HDCT785 so that the actual fuel consumption is obtained based on the standard. The observations of HDCT78465, HDCT78318, and HDCT78360 units that passed non-standard grade conditions found that the nonstandard grade road length that the dump truck traversed was 138.78 meters, and the total increase in the amount of fuel per hour was 0.97 (Table 9).
If the total tool working hours is multiplied by the increase in fuel consumption per hour, then the fuel consumption is obtained due to grade. If the grade that exceeds the standard is done, the production unit will continue to pass it, increasing fuel consumption [19]. Therefore, the amount of consumption caused by excess grade condition from the standard, which is $8 \%$, is $115,879.31$ liters for three months (Table 10).

The length of the road from non-standard road grades (distance 1) impacts the condition of excess fuel consumption compared to fixing the road grade by forming a standard grade. Suppose corrective action is taken by carrying out backfilling activities for non-standard road conditions. In that case, the AFCA costs can be reduced by $\$$ $59,098.44$ so that the total AFCA costs after reducing fuel are $\$ 541,956.49$ (Table 11). Previous studies related to road maintenance and monitoring processes using GPS/BA, DGPS and LIDAR can only work optimally with a road slope of $8 \%$ [20]. In the process of improving grade on roads with a slope of more than $8 \%$, filling material is required from overburden around the loading point (Fig. 6). So it is necessary to calculate the volume of overburden then the cost of equipment for road maintenance in the form of a dozer for levelling the material and a roller compactor that functions for road compaction.

Table 9. Comparison of the actual fuel consumption with the handbook against the fuel consumption value's fairness based on the unit specifications

\begin{tabular}{|c|c|c|c|c|c|c|}
\hline \multirow{2}{*}{ Unit } & \multirow{2}{*}{$\begin{array}{c}\text { Pit } \\
\text { location }\end{array}$} & \multicolumn{2}{|c|}{ Observation } & \multicolumn{2}{|c|}{$\begin{array}{c}\text { Actual fuel } \\
\text { consumption (ltr/hr) }\end{array}$} & \multirow{2}{*}{$\begin{array}{c}\text { Increasing high } \\
\text { to medium fuel } \\
\text { consumption } \\
(\text { ltr/hr })\end{array}$} \\
\hline & & Duration & Distance & High & Medium & \\
\hline HDCT78465 & Eco & 0.0125 & 143.06 & 3.43 & 2.45 & 0.98 \\
\hline HDCT78318 & Eco & 0.0097 & 108.00 & 2.68 & 1.91 & 0.77 \\
\hline HDCT78360 & Eco & 0.0153 & 165.28 & 4.09 & 2.92 & 1.17 \\
\hline \multicolumn{2}{|c|}{ Average } & & 138.78 & & & 0.97 \\
\hline
\end{tabular}

Table 10. Total fuel consumption from medium to high condition for type unit HD785

\begin{tabular}{ccccccc}
\hline Period & $\begin{array}{c}\text { Lt/HM } \\
\text { actual }\end{array}$ & $\begin{array}{c}\text { Total Fuel } \\
\text { consumption }\end{array}$ & $\begin{array}{c}\text { Total } \\
\text { HM }\end{array}$ & $\begin{array}{c}\text { Average } \\
\text { distance (m) }\end{array}$ & $\begin{array}{c}\text { Increasing } \\
\text { high to } \\
\text { medium fuel } \\
\text { consumption } \\
\text { (ltr/hr) }\end{array}$ & $\begin{array}{c}\text { Increasing } \\
\text { high to } \\
\text { medium fuel } \\
\text { consumption } \\
\text { (ltr) }\end{array}$ \\
\hline January & 84.9 & $3.590 .170,00$ & $42.307,30$ & & & $41.038,08$ \\
February & 83.5 & $2.709 .177,00$ & $32.455,80$ & 138.78 & 0.97 & $31.482,13$ \\
March & 84.24 & $3.765 .741,00$ & $44.700,10$ & & & $43.359,10$ \\
\hline
\end{tabular}


Table 11. The difference in AFCA costs before and after reduce fuel is implemented

\begin{tabular}{cccccc}
\hline \multirow{2}{*}{ Period } & $\begin{array}{c}\text { Reduce fuel } \\
\text { quantity }\end{array}$ & $\begin{array}{c}\text { Fuel price } \\
(\mathbf{\$})\end{array}$ & $\begin{array}{c}\text { Saving cost } \\
\mathbf{( \$ )}\end{array}$ & \multicolumn{2}{c}{ AFCA (\$) } \\
& $41.038,08$ & & $20.929,42$ & & \\
\hline January & \multirow{2}{*}{0.51} & $16.055,88$ & $601.054,93$ & $541.956,49$ \\
February & $31.482,13$ & 0.51 & $22.113,14$ & & \\
March & $43.359,10$ & & $59.098,44$ & & \\
\hline & Total & & \multicolumn{3}{c}{} \\
\hline
\end{tabular}

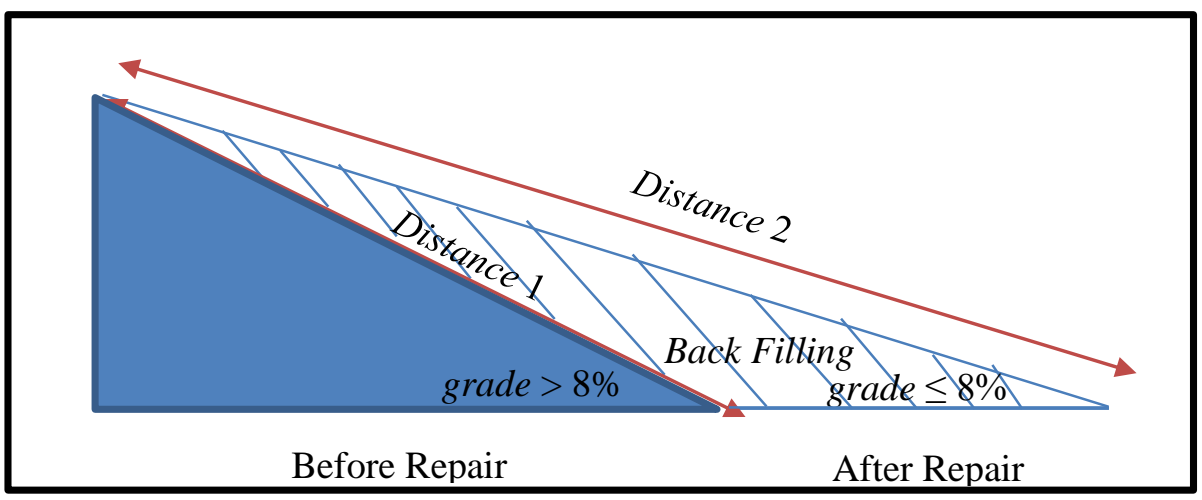

Fig 6. Illustration of mining road condition before repair (grade> 8\%) with repair condition in the form of backfilling material.

\section{CONCLUSION}

Based on the data and the cost opportunity analysis of this study, the improvement of the grade during planning to the application process in the field needs attention because the grade that exceeds the standard conditions will result in increased fuel consumption so that the resulting fuel ratio increases. This research proves that making the grade improvement can prevent the excess fuel consumption condition of $\$ 59,089.44$. Because this research only covers cost-benefit calculations, for further research, it is necessary to emphasize the design of the mine road, which supports the calculation of the fuel consumption requirements used by the mechanically operating mined equipment.

\section{ACKNOWLEDGMENT}

The author would like to thank all colleagues who have supported this research, especially the internal auditor team who always accompanies the operations area's improvement process.

\section{REFERENCES}

[1] E. Lizasoain-Arteaga, I. IndacoecheaVega, B. Alonso, and D. Castro-Fresno, "Influence of traffic delay produced during maintenance activities on the life cycle assessment of a road," J. Clean. Prod., vol. $253, \quad$ p. $120050, \quad 2020$, doi: 10.1016/j.jclepro.2020.120050.

[2] J. Baek and Y. Choi, "A New Method for Haul Road Design in Open-Pit Mines to Support Efficient Truck Haulage Operations," Applied Sciences, vol. 7, no. 7. 2017, doi: 10.3390/app7070747.

[3] Department of Resources Energy and Tourism, "Analyses of diesel use for mine haul and transport operations - several companies," Australian Goverment, 2010. Available:

https://www.energy.gov.au/publications/a nalyses-diesel-use-mine-haul-andtransport-operations-several-companies.

[4] S. R. Dindarloo and E. Siami-Irdemoosa, "Determinants of fuel consumption in mining trucks," Energy, vol. 112, pp. 232240, 2016, doi: 10.1016/j.energy.2016.06.085.

[5] H. Liu, M. O. Rodgers, and R. Guensler, "The impact of road grade on vehicle accelerations behavior, PM2.5 emissions, and dispersion modeling," Transp. Res. Part D Transp. Environ., vol. 75, no. September, pp. 297-319, 2019, doi: 10.1016/j.trd.2019.09.006. 
[6] B. Yazdani Boroujeni and H. C. Frey, "Road grade quantification based on global positioning system data obtained from real-world vehicle fuel use and emissions measurements," Atmos. Environ., vol. 85, pp. 179-186, 2014, doi: 10.1016/j.atmosenv.2013.12.025.

[7] M. V. Faria, G. O. Duarte, R. A. Varella, T. L. Farias, and P. C. Baptista, "How do road grade, road type and driving aggressiveness impact vehicle fuel consumption? Assessing potential fuel savings in Lisbon, Portugal," Transp. Res. Part D Transp. Environ., vol. 72, no. May, pp. 148-161, 2019, doi: 10.1016/j.trd.2019.04.016.

[8] M. Brown, S. Mercier, and Y. Provencher, "Road Maintenance with Opti-Grade®: Maintaining Road Networks to Achieve the Best Value," Transp. Res. Rec., vol. 1819, no. 1, pp. 282-286, Jan. 2003, doi: 10.3141/1819a-41.

[9] J. L. Collins, K. Fytas, and R. K. Singhal, "Design, construction and maintenance of surface mine haulage roads," Int. J. Surf. Mining, Reclam. Environ., vol. 1, no. 2, pp. 137-145, 1987, doi: 10.1080/09208118708944111.

[10] D. Hugo, S. P. Heyns, R. J. Thompson, and A. T. Visser, "Condition-triggered maintenance for mine haul roads with reconstructed-vehicle response to haul road defects," Transp. Res. Rec., vol. 2, no. 1989, pp. 254-260, 2007, doi: 10.3141/1989-71.

[11] C. Hoever and W. Kropp, "A model for investigating the influence of road surface texture and tyre tread pattern on rolling resistance," J. Sound Vib., vol. 351, pp. 161-176, 2015, doi: 10.1016/j.jsv.2015.04.009.

[12] B. Coutermarsh, "Velocity effect of vehicle rolling resistance in sand," $J$. Terramechanics, vol. 44, no. 4, pp. $275-$ 291, 2007, doi: 10.1016/j.jterra.2007.03.001.

[13] Caterpillar, "Caterpillar Performance Handbook," Catapillar Inc., p. 2264, 2015. Available:

http://nees.ucsd.edu/facilities/docs/Perfor mance_Handbook_416C.pdf.
[14] S. Park, A. A. Popov, and D. J. Cole, "Influence of soil deformation on off-road heavy vehicle suspension vibration," $J$. Terramechanics, vol. 41, no. 1, pp. 41-68, 2004, doi: 10.1016/j.jterra.2004.02.010.

[15] Y. Indonesianto, Pemindahan Tanah Mekanis. Yogyakarta: Program Studi Teknik Pertambangan UPN Veteran, 2012. Available:

https://opac.perpusnas.go.id/DetailOpac.a spx?id=806447.

[16] M. Nabella, "Analisis Pengaruh Kemiringan Jalan Dan Jarak Angkut Terhadap Konsumsi Bahan Bakar Dan Fuel Ratio Pada Kegiatan Penambangan Batuan Andesit di PT Gunung Sampurna Makmur," Bandung: Fakultas Teknik Universitas Islam Bandung (UNISBA), 2016.

Available: http://repository.unisba.ac.id/handle/1234 $56789 / 5637$.

[17] D. Sevendra, S. Sumarya, and Y. M. Anaperta, "Analisis Hubungan Total Resistance dan Kecepatan Terhadap Konsumsi Bahan Bakar Dumptruck Komatsu HD785 dan Caterpillar HD777 di PT. Semen Padang," Bina Tambang, vol. 3, no. 1, pp. 566-580, 2018. Available: http://ejournal.unp.ac.id/index.php/mining /article/view/9175.

[18] L. A. Carvalho et al., "Impact of grade distribution on the final pit limit definition," REM-International Eng. J., vol. 71, no. 4, pp. 621-629, 2018. Available:

https://www.scielo.br/j/remi/a/VQYS8Nk KJv7xYTNFpXqKSpg/?lang=en.

[19] S. H. Winarto, "Analisis Konsumsi Bahan Bakar HD777 dan Komatsu HD785-7 di PT Bukit Makmur pada Lokasi Kerja Sebuku, Kalimantan Selatan,” Bandung: Institut Teknologi Bandung, 2009. Available:

https://digilib.itb.ac.id/index.php/gdl/view $/ 13831$.

[20] R. Thompson and A. Visser, "Mine haul road maintenance management systems," J. South. African Inst. Min. Metall., vol. 103, no. 5, pp. 303-312, 2003. Available: https://hdl.handle.net/10520/AJA003822 3X_2861. 